Journal of Epidemiology and Public Health (2018), 3(2): 128-142

https://doi.org/10.26911/jepublichealth.2018.03.02.03

\title{
Multilevel Analysis on the Biological, Social Economic, and Environmental Factors on the Risk of Pneumonia in Children Under Five in Klaten, Central Java
}

\author{
Nurul Ulya Luthfiyana'), Setyo Sri Rahardjo 2), Bhisma Murti 1) \\ ${ }^{1)}$ Masters Program in Public Health, Universitas Sebelas Maret \\ ${ }^{2)}$ Faculty of Medicine, Universitas Sebelas Maret
}

\begin{abstract}
Background: Pneumonia is one of the leading causes of death in children under five in the world, particularly in the developing countries including Indonesia. Imbalance between host, agent, and environment, can cause the incidence of pneumonia. This study aimed to examine the biological, social economic, and environmental factors on the risk of pneumonia in children under five using multilevel analysis with village as a contextual factor.

Subjects and Method: This was an analytic observational study with case control design. The study was conducted in Klaten District, Central Java, from October to November, 2017. A total sample of 200 children under five was selected for this study by fixed disease sampling. The dependent variable was pneumonia. The independent variables were birth weight, exclusive breastfeeding, nutritional status, immunization status, maternal education, family income, quality of house, indoor smoke exposure, and cigarette smoke exposure. The data were collected by questionnaire and checklist. The data were analyzed by multilevel logistic regression analysis.

Results: Birth weight $\geq 2.500$ g $(\mathrm{OR}=0.13 ; 95 \% \mathrm{CI}=0.02$ to $0.77 ; \mathrm{p}=0.025)$, exclusive breastfeeding $(\mathrm{OR}=0.15 ; 95 \% \mathrm{CI}=0.02$ to $0.89 ; \mathrm{p}=0.037)$, good nutritional status $(\mathrm{OR}=0.20 ; 95 \%$ $\mathrm{CI}=0.04$ to $0.91 ; \mathrm{p}=0.038)$, immunizational status $(\mathrm{OR}=0.12 ; 95 \% \mathrm{CI}=0.02$ to $0.67 ; \mathrm{p}=0.015)$, maternal educational status $(\mathrm{OR}=0.18 ; 95 \% \mathrm{CI}=0.03$ to $0.83 ; \mathrm{p}=0.028)$, high family income $(\mathrm{OR}=0.25 ; 95 \% \mathrm{CI}=0.07$ to $0.87 ; \mathrm{p}=0.030)$, and good quality of house $(\mathrm{OR}=0.21 ; 95 \% \mathrm{CI}=0.05$ to $0.91 ; \mathrm{p}=0.037$ ) were associated with decreased risk of pneumonia. High indoor smoke exposure $(\mathrm{OR}=8.29 ; 95 \% \mathrm{CI}=1.49$ to $46.03 ; \mathrm{p}=0.016)$ and high cigarette smoke exposure $(\mathrm{OR}=6.37 ; 95 \%$ $\mathrm{CI}=1.27$ to $32.01 ; \mathrm{p}=0.024$ ) were associated with increased risk of pneumonia. $\mathrm{ICC}=36.10 \%$ indicating sizeable of village as a contextual factor. LR Test $\mathrm{p}=0.036$ indicating the importance of multilevel model in this logistic regression analysis.

Conclusion: Birth weight, exclusive breastfeeding, good nutritional status, immunizational status, maternal educational status, high family income, and good quality of house decrease risk of pneumonia. High indoor smoke exposure and high cigarette smoke exposure increase risk of pneumonia.
\end{abstract}

Keywords: pneumonia,biological, social economic, environmental factor, children under five

\section{Correspondence:}

Nurul Ulya Luthfiyana, Masters Program in Public Health, Universitas Sebelas Maret, Jl. Ir. Sutami 36 A, Surakarta 57126, Central Java. Email: ulya.luthfiyana@gmail.com.

\section{BACKGROUND}

Pneumonia is an important public health problem and the largest contributor to mortality in children under five years in the world, especially in developing countries. World Health Organization (WHO) and Maternal and Child Epidemiology Estimation Group (MCEE) in 2015 stated that more than 922,00o children under five died each year or more than 2,500 per day due to pneumonia. The proportion of under-five mortality accounts for about $16 \%$ of all under-five mortality in the world. The WHO estimates 156 million new cases of pneumonia in children per year with 20 million severe cases. A total of 61 million 
new cases of pneumonia in infants occurred in Southeast Asia (Rudan 2008: Ferdous, 2014). Africa and Southeast Asia are countries with the highest incidence and severity of pneumonia cases accounting for $30 \%$ and $39 \%$ of the global burden of pneumonia (Zar et al., 2013; WHO \& UNICEF, 2015).

Pneumonia is the biggest cause of under-five mortality in Indonesia. Based on the results of Basic Health Research (RISKESDAS) in 2013, the mortality rate of children under five in Indonesia is 27 / 1,000 live births. Defects $15 \%$ of all underfive mortality in Indonesia is caused by pneumonia. By 2015, the proportion of under-five mortality attributable to pneumonia increased to $16 \%$ of 25,000 under-fives. The prevalence of pneumonia in infants in Indonesia in 2015 and 2016 is $2.3 \%$ and $2.1 \%$ respectively, with the number of cases reaching consecutive 554,650 cases and 503,738 cases (Ministry of Health, 2017).

Prevalence of infant pneumonia in Central Java in 2016 is $0.7 \%$ (20,662 cases / 2,712,253 toddlers) (Ministry of Health $\mathrm{RI}, 2017)$. Klaten Regency is included in 3 districts in Central Java with the highest prevalence of pneumonia in 2015 with prevalence of pneumonia in children under $5.7 \%$ (3,926 cases / 69,351 toddlers). This number increased by $15.6 \%$ compared to 2014. Pneumonia accounted for $5.8 \%$ of under-five mortality in Klaten District (Klaten District Health Office, 2016).

Pneumonia occurs due to an imbalance between the causative agent, the host, and the environment. Based on WHO data, $50 \%$ of pneumonia was caused by Streptococcus pneumoneae and 30\% by Haemophylus influenzae type B (HiB).

Risk factors for pneumonia associated with host and environment include a history of low birth weight (LBW), non- exclusive breastfeeding, malnutrition, vitamin A deficiency, and incomplete immunization status. Air pollution in the home comes from the use of biomass as a cooking fuel or the presence of family members who smoke, as well as the quality of homes that do not meet healthy requirements (Hadisuwarno et al., 2015; Nguyen et al., 2017).

The high prevalence of pneumonia suggests that pneumonia is an important issue that must be controlled immediately. Control of pneumonia in children underfive consider factors located at the micro level and macro level.

The purpose of this study was to analyze the effect of birth weight, exclusive breastfeeding, nutritional status, immunization status, maternal education level, family income, home quality, exposure to biomass fumes, and family smoking activity against the risk of pneumonia incidence in under-five children by considering the condition village areas as contextual factors at the community level.

\section{SUBJECTS AND METHOD}

\section{Study Design}

The study design was observational analytic with a case-control approach. It was conducted in Klaten, Central Java from October to November 2017.

\section{Population and Sample}

The target population in this study was all children under five. The source population was children living in the working area of Bayat, Jogonalan I, Kalikotes, Klaten Selatan, and Gantiwarno Community Health Centers covering 25 villages. Sample size in this study was 200 study subjects selected using fixed disease sampling. The study subjects consisted of 2 groups: 100 cases and 100 controls. The case group consisted of children under-five suffering from pneumonia based on Integrated Management Guideline of Sick Child (MTBS). The 
Journal of Epidemiology and Public Health (2018), 3(2): 128-142

https://doi.org/10.26911/jepublichealth.2018.03.02.03

control group consisted of children underfive who did not contract pneumonia.

\section{Operational Definition of Variables}

Pneumonia was defined as respiratory tract infections in infants characterized by the presence of a cough and/or difficulty in breathing with other clinical signs such as increased breathing frequency and the chest retraction. Assessment and diagnosis of pneumonia were conducted by trained physicians or paramedics using the Integrated Management of Toddlers Integrated Management (MTBS) manual.

Birth weight was defined the infant weight at birth regardless of gestational age with the normal category if weight was 2500 gram or more.

Exclusive breastfeeding was defined breastfeeding from birth to 6 months of age without supplementary feeding and/or beverages except for medications or vaccines with medical indications.

Nutritional status was defined as the nutritional status calculated based on WHO anthropometric measurements of Z-score body weight for age, with underweight category (between -3 SD and $<-2$ SD) and normoweight category (between $-2 \mathrm{SD}$ and +2 SD).

Immunization status was defined as the completeness of immunization that had been scheduled according to age based on the recommendation by Ministry of Health.

Mother's education level was defined as the highest attainable education.

Family income was defined as the amount of monthly income earned by the family in the form of the honorarium, rent, including subsidy. If family income was more than or equal to District Minimum Wage it was categorized as high income.

House quality was defined as the condition of the physical environment of the house or the components of the house based on the KEPMENKES guideline No. 829 / Menkes / SK / VII / 1999 on Housing Health Requirements covering spatial conditions, the state of the ceiling, walls, floors, bedroom windows and living rooms, kitchen smoke holes, lighting, density.

Exposure to fumes of biomass fuels was defined as exposure to house fumes arising from burning of wood, charcoal, husk, oil and other biomass for cooking based on PERMENKES Number 1077 / Menkes / PER / V / 2011.

Indoor smoking was defined as the presence of family members who smoked inside the house.

The data were collected by questionnaire and checklist.

\section{Data Analysis}

Data were analyzed by a multilevel logistic regression model with Stata 13 program to estimate the effect of the independent variable on the dependent variable at the individual level (level 1) and contextual influence of village at the community level (level 2).

\section{Research Ethics}

This study has obtained ethical approval from the Research Ethics Commission of Dr. RSUD. Moewardi Surakarta.

\section{RESULTS}

1. Characteristics of Study Subjects

Characteristics of study subjects shown in Table 1 explain that the subject of the study mostly aged 12-59 months ie as many as 161 subjects (80.5\%). By sex, the number of study subjects was almost comparable between males and females with 98 male subjects (49.0\%) and 102 female subjects (51.0\%). Most mothers of the study subjects aged 20-35 years (74.0\%), had $\geq$ Senior High School attainment (48.0\%), and worked at home as housewives (42.5\%). 
Table 1. Characteristics of Study Subjects

\begin{tabular}{lcc}
\hline \multicolumn{1}{c}{ Characteristics } & N & \% \\
\hline Age of Children Under-Five & 39 & 19.5 \\
$2-<12$ month & 161 & 80.5 \\
12-59 month & & \\
Gender & 98 & 49.0 \\
Male & 102 & 51.0 \\
Female & & \\
Age of Mother & 1 & 0.5 \\
<20 years & 148 & 74.0 \\
20-35 years & 51 & 25.5 \\
$>35$ years & & \\
Education & 4 & 2.0 \\
No Schooling & 16 & 8.0 \\
Elementary School & 74 & 37.0 \\
Junior High School & 96 & 48.0 \\
Senior High Shcool & 10 & 5.0 \\
Post Graduate & & \\
Employment & 85 & 42.5 \\
Housewives & 18 & 9.0 \\
Laborers & 28 & 14.0 \\
Farmer & 41 & 20.5 \\
Entrepreneur & 20 & 10.0 \\
Privat employers & 8 & 4.0 \\
Civil servants & & \\
\hline
\end{tabular}

\section{Bivariate Analysis}

The bivariate analysis describes the effect of one independent variable to one dependent variable. The result of the bivariate analysis shows that all independent variables significantly affect the incidence of pneumonia in infants. The results of the bivariate analysis are shown in Table 2. It shows the results of Chi-Square test between birth weight, exclusive breastfeeding, nutritional status, immunization status, maternal education level, family income, home quality, exposure to biomass fumes, and family smoking activity, and the risk of pneumonia.

\section{Multilevel Analysis}

Table 3 shows the results of multiple logistic regression. Factors that decreased the risk of pneumonia in children under five were normal birth weight $(\mathrm{OR}=0.13$;
95\% CI $=0.02$ to $0.77 ; \mathrm{p}=0.025)$, exclusive breast feeding $(\mathrm{OR}=0.15 ; 95 \% \mathrm{CI}=0.02$ to o.89; $\mathrm{p}=0.037$ ), good nutritional status $(\mathrm{OR}=0.20 ; 95 \% \mathrm{CI}=0.04$ to $0.91 ; \mathrm{p}=$ o.038), complete immune status (OR = $0.12 ; 95 \% \mathrm{CI}=0.02$ to $0.67 ; \mathrm{p}=0.015)(\mathrm{OR}$ $=0.18 ; 95 \% \mathrm{CI}=0.03$ to $0.83 ; \mathrm{p}=0.028)$, family income $\geq$ Rp. 1,400,000 $(\mathrm{OR}=0.25$; $95 \% \mathrm{CI}=0.07$ to $0.87 ; \mathrm{p}=0.030)$, and good quality of house $(\mathrm{OR}=0.21 ; 95 \% \mathrm{CI}=$ 0.05 to $0.91 ; \mathrm{p}=0.037$ ).

Exposure of biomass fuel fumes (OR $=8.29 ; 95 \% \mathrm{CI}=1.49$ to $46.03 ; \mathrm{p}=0.016)$ and secondhand smoking in the house (OR $=6.37 ; 95 \% \mathrm{CI}=1.27$ to $32.01 ; \mathrm{p}=0.024$ ) increased risk of pneumonia in children under five. There was a contextual effect of village conditions on the risk of pneumonia in children under five with $\mathrm{ICC}=36.10 \%$ (LR Test $\mathrm{p}=0.036$ ). 
Journal of Epidemiology and Public Health (2018), 3(2): 128-142

https://doi.org/10.26911/jepublichealth.2018.03.02.03

Table 2. The results of Chi-Square on the risk factor of Pneumonia in Children under Five

\begin{tabular}{|c|c|c|c|c|c|c|c|c|c|c|}
\hline \multirow{3}{*}{ Variable } & \multicolumn{4}{|c|}{ Pneumonia Status } & \multirow{2}{*}{\multicolumn{2}{|c|}{ Total }} & \multirow{3}{*}{ OR } & \multicolumn{2}{|c|}{ 95\% CI } & \multirow{3}{*}{$\mathbf{p}$} \\
\hline & \multicolumn{2}{|c|}{ No } & \multicolumn{2}{|c|}{ Yes } & & & & & & \\
\hline & $\mathbf{n}$ & $\%$ & $\mathbf{n}$ & $\%$ & $\overline{\mathbf{n}}$ & $\%$ & & Upper & Lower & \\
\hline \multicolumn{11}{|l|}{ Birth Weight } \\
\hline $\operatorname{BBLR}(<2,500 \mathrm{~g})$ & 8 & 30.8 & 18 & 69.2 & 26 & 100.0 & 0.39 & 0.16 & 0.95 & 0.036 \\
\hline $\operatorname{BBLN}(\geq 2,500 \mathrm{~g})$ & 92 & 52.9 & 82 & 47.1 & 174 & 100.0 & & & & \\
\hline \multicolumn{11}{|l|}{ Exclusive } \\
\hline \multicolumn{11}{|l|}{ Breastfedeing } \\
\hline No & 5 & 11.9 & 37 & 88.1 & 42 & 100.0 & 0.09 & 0.03 & 0.24 & $<0.001$ \\
\hline Yes & 95 & 60.1 & 63 & 39.9 & 158 & 100.0 & & & & \\
\hline \multicolumn{11}{|l|}{ Nutritional Status } \\
\hline Poor & 7 & 10.8 & 58 & 89.2 & 65 & 100.0 & 0.05 & 0.02 & 0.12 & $<0.001$ \\
\hline Good & 93 & 68.9 & 42 & 31.1 & 135 & 100.0 & & & & \\
\hline \multicolumn{11}{|l|}{ Imunization Status } \\
\hline Incomplete & 9 & 22.0 & 32 & 78.0 & 41 & 100.0 & 0.21 & 0.09 & 0.46 & $<0.001$ \\
\hline Complete & 91 & 57.2 & 68 & 42.8 & 159 & 100.0 & & & & \\
\hline \multicolumn{11}{|l|}{ Maternal education } \\
\hline$<$ Senior high school & 30 & 31.9 & 64 & 68.1 & 94 & 100.0 & 0.24 & 0.13 & 0.43 & $<0.001$ \\
\hline$\geq$ Senior high school & 70 & 66.0 & 36 & 34.0 & 106 & 100.0 & & & & \\
\hline \multicolumn{11}{|l|}{ Family Income } \\
\hline$<\mathrm{Rp} 1,400,000$ & 19 & 21.8 & 68 & 78.2 & 87 & 100.0 & 0.11 & 0.05 & 0.21 & $<0.001$ \\
\hline$\geq \mathrm{Rp} 1,400,000$ & 81 & 71.7 & 32 & 28.3 & 113 & 100.0 & & & & \\
\hline \multicolumn{11}{|l|}{ House Quality } \\
\hline Poor quality of house & 12 & $13 \cdot 3$ & 78 & 86.7 & 90 & 100.0 & 0.03 & 0.01 & 0.08 & $<0.001$ \\
\hline Good quality of house & 88 & 80.0 & 22 & 20.0 & 110 & 100.0 & & & & \\
\hline \multicolumn{11}{|l|}{$\begin{array}{l}\text { Exposure of biomass } \\
\text { fuel }\end{array}$} \\
\hline Low & 87 & 83.7 & 17 & 16.3 & 104 & 100.0 & 32.67 & 14.94 & 71.43 & $<0.001$ \\
\hline High & 13 & 13.5 & 83 & 86.5 & 96 & 100.0 & & & & \\
\hline \multicolumn{11}{|l|}{$\begin{array}{l}\text { Secondhand } \\
\text { smoking in the house }\end{array}$} \\
\hline No & 58 & $77 \cdot 3$ & 17 & 22.7 & 75 & 100.0 & 6.74 & 3.50 & 12.98 & $<0.001$ \\
\hline Yes & 42 & 33.6 & 83 & 66.4 & 125 & 100.0 & & & & \\
\hline
\end{tabular}

\section{DISCUSSION}

\section{The association between birth weight and pneumonia}

The results showed that there was a significant effect of birth weight on the risk of pneumonia in children under five. Children under five who had normal birth weight had a lower risk for experiencing pneumonia 0.13 times compared with children under five who have low birth weight. Conversely, underweight children $(<2,500$ grams $)$ had a 7.69 times risk of developing pneumonia than those with normal weight $(\geq 2,500$ grams $)$.

The results of this study is consistent with a study by Stekelenburg et al. (2002), which reported that low birth weight had an effect on the risk of pneumonia in children under five. Children with low birth weight tend to be susceptible to decreased respiratory function and so have an increased risk of respiratory disease during childhood.

This study is consistent with a study in China by Lu et al. (2013), which reported 
that low birth weight was associated with

children with hand, foot, and mouth lower respiratory tract infections in disease.

Tabel 3. The results of path analysis on the risk factor of pneumonia

\begin{tabular}{|c|c|c|c|c|}
\hline \multirow{2}{*}{ Independen Variable } & \multirow{2}{*}{$\mathbf{O R}$} & \multicolumn{2}{|c|}{$95 \% \mathrm{CI}$} & \multirow[t]{2}{*}{$\mathbf{p}$} \\
\hline & & Lower & Upper & \\
\hline \multicolumn{5}{|l|}{ Fixed Effect } \\
\hline Normal birthweight & 0.13 & 0.02 & 0.77 & 0.025 \\
\hline Exclusive breastfeeding & 0.15 & 0.02 & 0.89 & 0.037 \\
\hline Good nutritional status & 0.20 & 0.04 & 0.91 & 0.038 \\
\hline Complete imunization & 0.12 & 0.02 & 0.67 & 0.015 \\
\hline Maternal education ( $\geq$ Senior High School) & 0.18 & 0.03 & 0.83 & 0.028 \\
\hline $\begin{array}{l}\text { Family income } \geq \text { Minimum Regional Wage } \\
(\operatorname{Rp} 1,400,000)\end{array}$ & 0.25 & 0.07 & 0.87 & 0.030 \\
\hline Good quality of house & 0.21 & 0.05 & 0.91 & 0.037 \\
\hline Exposure of biomass fuel & 8.29 & 1.49 & 46.03 & 0.016 \\
\hline Secondhand smoking in the house & 6.37 & 1.27 & 32.01 & 0.024 \\
\hline \multicolumn{5}{|l|}{$\begin{array}{l}\text { Random Effect } \\
\text { Village }\end{array}$} \\
\hline Var (constant) & 1.85 & 0.28 & 12.03 & \\
\hline $\mathrm{N}$ LR test vs. logistic regression: $\mathrm{p}=0.036$ & 200 & & & \\
\hline Intraclass Correlation (ICC) $=36.10 \%$ & & & & \\
\hline
\end{tabular}

A study by Hadisuwarno et al. (2015) also reported that underweight children with a history of low birthweight had a 3.10 fold increased risk compared with normoweight children $(\mathrm{OR}=3.10 ; 95 \% \mathrm{CI}=1.34$ to 6.86). Children under five with low birthweight have impaired immune function. The more severe the growth retardation experienced by the fetus, the more severe the damage to lung structure and function. Immunocompetence disorder will persist throughout childhood (Grant et al., 2011).

\section{The association between exclusive breastfeeding and pneumonia}

The result showed that there was a significant effect of exclusive breastfeeding on the risk of pneumonia in children under five. Children who got exclusive breastfeeding had a lower risk of experiencing pneumonia 0.15 times compared to children who did not get exclusive breastfeeding.
The finding of this study is consistent with a study by Hanieh et al. (2015), which reported that infants who receive exclusively breastfeeding had a lower risk of pneumonia than those who did not receive exclusive breastfeeding. A study by Fikri (2016) found that infants who were not exclusively breastfed for 6 months had more risk of pneumonia than those who were exclusively breastfed for 6 months.

This study is also consistent with a meta-analysis by Lamberti et al. (2013). Lamberti et al. (2013) reported that suboptimal breastfeeding elevated the risk of pneumonia morbidity and mortality outcomes across age groups. In particular, pneumonia mortality was higher among not breastfed compared to exclusively breastfed infants 0-5 months of age (RR: 14.97; 95\% CI: 0.67-332.74) and among not breastfed compared to breastfed infants and young children 6-23 months of age (RR: 1.92; 95\% CI: 0.79-4.68). Lamberti et al. (2013) 
Journal of Epidemiology and Public Health (2018), 3(2): 128-142

https://doi.org/10.26911/jepublichealth.2018.03.02.03

highlighted the importance of breastfeeding during the first 23 months of life as a key intervention for reducing pneumonia morbidity and mortality.

Breast milk contains immune substances against infections such as proteins, lysozyme, lactoferrin, immunoglobulins, and antibodies against bacteria, viruses, fungi, and other pathogens. Breast milk also increases the antibody response to pathogens in the respiratory tract and boosts the immune system. Therefore, exclusive breastfeeding reduces the infant mortality rate due to various diseases such as pneumonia and speeds recovery when sick (Grant et al., 2011). Infants under 6 months of age who were not exclusively breastfed were five times more likely to die of pneumonia than infants who received exclusive breastfeeding (WHO \& UNICEF, 2013).

\section{The association between nutri- tional status and pneumonia}

The result showed that there was a significant effect of nutritional status on the risk of pneumonia in children under five. Children with good nutritional status had 0.20 times lower risk of experiencing pneumonia compared to children with poor nutritional status.

The finding of this study is consistent with a study by Jackson et al. (2013) which reported that children with poor nutrition had 4.47 times risk of pneumonia compared with children who had good nutrition. Lestari et al. (2017) found that nutritional status had a direct effect on the of pneumonia. Poor nutritional status increased the risk of pneumonia by 3.44 times in children under five.

Malnutrition decreases immune capacity to respond to pneumonia infection including granulocyte dysfunction, decreased complement function, and causes micronutrient deficiency, disruption of bacteri- cidal phagocyte activity, and decreased antipneumococcal IgA (Ibrahim et al., 2017). Adequate nutrition maintains the growth and development of children under five, which eventually prevents children from infectious diseases.

\section{The association between complete immunization and pneumonia}

A community-level, controlled study of mass influenza vaccination of children in Russia demonstrated a significant reduction of influenza-like illness in children, as well as a reduction in influenza-related diseases in the elderly. Simulation models suggest that vaccinating just $20 \%$ of the population aged 6 months to 18 years could reduce influenza in the total US population by $46 \%$ (Cohen et al., 2010).

In Indonesia, Haemophilus Influenzae Type b (Hib) vaccine has been included in the basic immunization program for infant. However, studies on the effect of immunization status on the incidence of child pneumonia are lacking.

The result of the present study showed that there was a significant effect of the complete immunization on the risk of pneumonia. Children with complete immunization had 0.12 times risk of experiencing pneumonia compared with those with incomplete immunization.

The result is consistent with a study by Hadisuwarno et al. (2015) which reported that there was a relationship between immunization status and the incidence of pneumonia in children under five. Children who did not get complete immunization according to the recommendation of the Ministry of Health had 6.37 times risk of experiencing pneumonia compared with children who got complete immunization.

Complete immunization according to age in children under five forms the immune system in the body. According to World Health Organization (WHO), the 
basic immunization to prevent the risk of preventable diseases includes Haemophylus influenza type B (HiB) immunization, which prevents pneumonia. According to WHO \& UNICEF (2013) full immunization can prevent infection that causes pneumonia. Oliwa et al. (2017) reported that immunization is an appropriate preventive measure to reduce the risk of respiratory tract infections including pneumonia by giving the vaccine of Streptococcus pneumoniae, Haemophilus influenza type B (HiB), influenza, pertussis, measles and tuberculosis.

\section{The association between education level and pneumonia}

The result of this study showed that there was an effect of maternal education level on the risk of pneumonia. Children with higheducated mothers ( $\geq$ Senior high school) had 0.18 times lower risk of developing pneumonia compared with children with low-educated mothers.

The present study is consistent with a cross-sectional study was conducted in India among 460 mothers of under-five children. This study in India reported that age and education level of mothers had a significant association with the knowledge as well as with perception. There was a significant association between level of knowledge and perception of childhood pneumonia among these mothers (Pradhan et al., 2016).

The result of this study is consistent with study by Nirmolia et al. (2017), which reported that there was a significant relationship between maternal education and the risk of pneumonia. Children with low-educated mothers had 1.53 times risk of pneumonia compared to those with higheducated mothers.

Maternal education is a factor that indirectly affects the risk of pneumonia. The result of this study is consistent with
Anwar and Dharmayanti (2014), which reported that underweight children with low educated mothers had a higher risk of pneumonia compared to those with higheducated mothers $(\mathrm{OR}=1.20 ; 95 \%$ CI 1.11 to 1.30; $\mathrm{p}<0.001)$. A high educated mother has the ability to receive knowledge and information about pneumonia and its prevention (Rashid, 2013).

Azab et al. (2014) suggest that welleducated mothers may be more aware of the risk factors for pneumonia, prevention of pneumonia, recognizing early and appropriate pneumonic signs of pneumonia in the immediate aftermath of these symptoms. The results showed that under-five children with lower educated women had a higher risk of developing pneumonia compared to well-educated mothers (OR = $3.80 ; 95 \%$ CI 2.12 to $6.70 ; \mathrm{p}=0.001$ ).

\section{The association between family income and pneumonia}

The result showed that there was an effect of family income on the risk of pneumonia. Children from high-income families had 0.25 times lower risk of developing pneumonia compared with children.

The result of this study is consistent with study by Nguyen et al. (2017), which reported that children from families with low socioeconomic status were at higher risk of infectious diseases than those from families with high socio-economic status. Socio-economic status determines the fulfillment of the life need including home sanitation and nutritious food.

The result of this study is consistent with Azab et al. (2014), which reported that low family income increased the risk of pneumonia $(\mathrm{OR}=2.2 ; 95 \% \mathrm{CI}, 0.99$ to 4.78, $\mathrm{p}=0.047$ ). Low-income families have limitations in meeting health-related living needs and access to preventative and curative measures. Karsidi (2008) points out that low-income families can only 
Journal of Epidemiology and Public Health (2018), 3(2): 128-142

https://doi.org/10.26911/jepublichealth.2018.03.02.03

partially meet the daily basic needs, while high-income families can meet all the desires they want including a housing with good quality, nutritious food, and other needs.

The result of this study is supported by the study of Azab et al. (2014), which reported that low family income increased risk of pneumonia in children under five $(\mathrm{OR}=2.2 ; 95 \% \mathrm{CI}, 0.99$ to $4.78, \mathrm{p}=0.047)$.

\section{The association between quality house and pneumonia}

The result showed that there was a significant effect of the house quality on the risk of pneumonia in children under five. Children who lived in high quality homes had a lower risk of experiencing pneumonia than those who lived in low quality homes.

The result of this study is consistent with Sari et al. (2014), which reported that the condition of the physical environment of houses that do not meet health requirements increased the risk of disease transmission. This study found that physical environment of the house (i.e. temperature, intensity of natural lighting, type of house wall, house floor, ventilation, humidity, and occupancy density) is significantly related to the risk of pneumonia. The Indonesian Government has established a regulation on the housing health requirements, namely the Decree of the Minister of Health of the Republic of Indonesia No. 829 / MENKES / SK / VII / 1999 on Housing Health Requirements. Another study reported that about $30 \%$ of housing units did not meet the healthy requirements (Klaten District Health Office, 2016).

This study is also consistent with Azhar and Perwitasari (2014), Padmonobo et al. (2013), and Zairinayati et al. (2013), which point out that the physical environment of the house that does not meet health requirements can increase the risk of diseases such as tuberculosis and pneumonia.

\section{The association between exposure} to biomass fuel fumes and pneumonia

Almost 3 billion people worldwide burn solid fuels indoors. These fuels include biomass and coal. Although indoor solid fuel smoke is likely a greater problem in developing countries, wood burning populations in developed countries may also be at risk from these exposures (Sood, 2012). Despite the large population at risk worldwide, the effect of exposure to indoor solid fuel smoke has not been adequately studied in Indonesia.

The result of this study showed that there was a significant effect of the exposure to biomass fuel fumes on the risk of pneumonia. Children with high smoke exposure to biomass fuels had 8.29 times higher risk of developing pneumonia compared with those with low smoke exposure.

The result of this study is consistent with Bruce et al. (2013), which reported that homes using the type of biomass energy ingredients while cooking had a higher risk of pneumonia incidence than those not using the type of biomass (OR = $1.73 ; 95 \% \mathrm{CI}=1.47$ to $2.03 ; \mathrm{p}=0.046)$. Patel et al. (2013) reported that the use of biomass energy sources for cooking increased air pollution which led to pneumonia in infants $(\mathrm{OR}=1.53$; $95 \% \mathrm{CI}=$ 1.21 to 1.93$)$.

The result of this study is also supported by Sanbata et al. (2014), which reported that children living at home with biomass fuels while cooking had 3 times higher risk of Accute Respiratory Infection (ARI) or pneumonia compared with those not living at home with biomass fuels.

Exposure to cooking fuel fumes can come from wood, charcoal, husk, and other 
biomass. The use of biomass fuels such as firewood causes the risk of pneumonia treatment failure and aggravates infection (Kelly et al., 2016). Fuel or charcoal containing carbon monoxide, organic gas, particulate matter, and nitroxide worsen health problems in the body, including Acute Respiratory Infections and pneumonia, especially in infants. The study by Wichmann and Voyi (2006) showed that cooking activities using biomass fuel caused pollution and increased the risk of pneumonia compared with those using electric or gas stoves.

According to World Bank (2012), around $40 \%$ of households in Indonesia were still using biomass fuel as energy for cooking with traditional stoves, especially in rural areas. Central Java, the seconddensely populated province in Indonesia has the largest biomass fuel users of more than 4 million households. The fuel produces pollutants in high concentration due to the incomplete combustion process. The use of cooking fuels such as charcoal, wood, petroleum, and coal results in the risk of air pollution and /or chemical contamination in the home such as carbon dioxide (CO2), carbon monoxide (CO), sulfur dioxide (SO2), hydrogen sulfide ( $\mathrm{H} 2 \mathrm{~S}$ ), and dust particles with $10 \mu$ (PM10) diameter, which increase the risk of ARI. The use of biomass fuels for cooking should be supported by qualified kitchen constructions such as kitchen holes and energy efficient furnaces to reduce smoke exposure (World Bank, 2012).

\section{The association between second- hand smoking and pneumonia}

The result showed that there was a significant effect of the secondhand smoking on the risk of pneumonia children under five. Children living with family members who smoked had 6.37 times higher risk of developing pneumonia compared with those living with nonsmoking family members.

The result of this study was in line with the study of Suzuki et al. (2009) in Vietnam, which reported that air pollution from cigarette smoke increased the risk of pneumonia in children under five $(\mathrm{OR}=$ 1.55; $95 \% \mathrm{CI}=1.25$ to $1.92 ; \mathrm{p}<0.001$ ). Similarly, Sofia (2017) reported that children living with family members who smoked were 1.9 times more likely to develop pneumonia than those living with family members who did not smoke (OR = 1.9; $95 \% \mathrm{CI}=1.1$ to $3.4 ; \mathrm{p}=0.001$ ).

This study is consistent with a study in Brazil by Sigaud et al. (2016), which reported an association between secondhand smoking in the home and respiratory morbidity in preschool children.

Patel et al. (2013) explain that pneumonia is a serious disease problem caused by various factors, one of them is smoke. Polycyclic Aromatic Hydrocarbon (PAHS) is harmful to human health derived from the burning of tobacco products that are normally in the form of tobacco smoke (Environmental Tobacco Smoke / ETS). Cigarette smoke contains toxic and carcinogenic substances and can cause airway irritation by sulfur dioxide, ammonia, and formaldehyde (Hidayat et al., 2012).

\section{The contextual effect of village condition on pneumonia}

Multilevel analysis results in the value of ICC $=36.10 \%$. It means that the conditions at each village level have a contextual influence on $36.10 \%$ of the variation of pneumonia risk in children under five in this study population. This findings support the epidemiological triad model, which explains that the occurence of a disease is caused by the influences of host, agent, and environmental factors. The environment outside the individual (host) plays an 
Journal of Epidemiology and Public Health (2018), 3(2): 128-142

https://doi.org/10.26911/jepublichealth.2018.03.02.03

important role in the increased risk of pneumonia in children (Gordon in Marti, 2016).

This study found that $40 \%$ of the total 25 villages under study were classified as poor. Village poverty causes the villagers' inability to fulfill nutritional needs, housing ownership with sanitation that meets health requirements, and access to health facilities. This situation will also affect the condition of the surrounding environment to be unhealthy. In addition, the lack of prevention efforts against the incidence of a disease in the community may increase the risk of the risk of complex health problems including pneumonia in infants. Living in poor communities can also cause psychosocial stress, which can lead to negative behaviors that can negatively impact the health of the people around them, such as smoking behavior (Wang et al., 2007; Adesanya and Chiao, 2016).

This study is consistent with another multilevel study conducted in Indonesia by Yunita et al. (2016), which reported that there was the effect of contextual conditions of village on pneumonia in toddler (ICC = $36.97 \%$ exceeding the 5 to $8 \%$ threshold).

Machmud (2009) reported that the degree of health and poverty of people in a region affect each other. Revenue increase does not automatically guarantee poverty reduction unless the health status of the poor was also improved. Financing of health services should also receive attention so that there is an increase in health status, this will have an impact on increasing population income.

The condition of poverty also affects the public health behavior of each village which was also different. Villagers whose citizens were largely accessible to health information tend to have a heightened awareness of health and will usually influence the surrounding community to get together for health care. On the other hand, people in poor neighborhoods have limited access to health information and tend to had less health awareness, the surrounding environment can be affected and ignored by negative behavior (Abbey et al., 2016).

The field finding of this study also showed that the conditions of the settlements in each village were different. There were several villages with houses distant from one to another, and there were some villages with narrow areas and dense population. The lighting to pass through the windows was often covered by another house that caused humidity and air temperature inside the house (Wulandari, 2014).

This study concludes that birth weight, exclusive breastfeeding, good nutritional status, immunizational status, maternal educational status, high family income, and good quality of house decrease risk of pneumonia. High indoor smoke exposure and high cigarette smoke exposure increase risk of pneumonia.

The results of this study can be used to inform interventions to reduce the high burden of pneumonia in rural settings such as Klaten, Central Java, Indonesia.

Further studies are suggested with multilevel analysis to account for not only the effects of variables in the present study but also other risk factors like child age, father's education level, and history of upper respiratory tract infection and diarrhea (Dadi et al., 2014), while accounting for the contextual effects of village.

\section{REFERENCE}

Abbey M, Chinbuah MA, Gyapong M, Bartholomew LK, Borne B (2016). Community perceptions and practices of treatment seeking for childhood pne- 
umonia: A mixed methods study in a rural district, Ghana. BMC Public Health, 16(1): 1-10.

Adesanya OA, Chiao C (2016). A multilevel analysis of lifestyle variations in symptoms of acute respiratory infection among young children under five in Nigeria. BMC Public Health, 16(1): 1-11.

Ahmadi (2008). Manajemen penyakit berbasis wilayah. Jakarta: PT. Kompas Media Nusantara.

Anwar A, Dharmayanti I (2014). Pneumonia pada anak balita di Indonesia. Jurnal Kesehatan Masyarakat Nasional, 8(8): 359-365.

Azab S, Sherief LM, Saleh SH, Elsaeed WF, Elshafie MA, Abdelsalam S (2014). Impact of the socioeconomic status on the severity and outcome of community-acquired pneumonia among Egyptian children: a cohort study. Infectious Diseases of Poverty, 14(3): 1-7.

Azhar K, Perwitasari D (2014). Kondisi fisik rumah dan perilaku dengan prevalensi TB paru di Propinsi Dki Jakarta, Banten dan Sulawesi Utara.Media Penelitian dan Pengembangan Kesehatan, 23(4): 172-181.

Bruce NG, Dherani MK, Das JK, Balakrishnan K, Adair RH, Bhutta ZA, Pope D (2013). Control of household air pollution for child survival: Estimates for intervention impacts. BMC Public Health, 13(3): 1-13.

Cohen SA, Ahmed S, Klassen AC, Agree EM, Louis TA, Naumova EN (2010). Childhood Hib vaccination and pneumonia and influenza burden in US seniors. Vaccine. 28(28): 44624469.

Dadi AF, Kebede Y, Birhanu Z (2014). Determinants of Pneumonia in Children Aged Two Months to Five
Years in Urban Areas of Oromia Zone, Amhara Region, Ethiopia. Open Access Library Journal. 01(08):1-10.

Dinas Kesehatan Kabupaten Klaten (2016). Profil Kesehatan Kabupaten Klaten Tahun 2015. www.depkes.go.id/resources/download/profil/profil_kab_ kota_2015/3310_jateng_kab_klaten _2015. Diakses Maret 2017.

Fikri BA (2016). Analisis faktor risiko pemberian ASI dan ventilasi kamar terhadap kejadian pneumonia balita. The Indonesian Journal of Public Health, 11(1): 14-27.

Grant CC, Wall CR, Gibbons MJ, Morton SM, Santosham M, Black RE (2011). Child nutrition and lower respiratory tract disease burden in New Zealand: A global context for a national perspective. Journal of Paediatrics and Child Health, 47(8): 497-504.

Hadisuwarno W, Setyoningrum RA, Umiastuti P (2015). Host factors related to pneumonia in children under 5 years of age. Paediatrica Indonesiana, 55(5): 248-251.

Hanieh S, HaTT, Simpson JA, Thuy TT, Khuong NC, Thoang DD, Biggs BA (2015). Exclusive breast feeding in early infancy reduces the risk of inpatient admission for diarrhea and suspected pneumonia in rural Vietnam: A prospective cohort study. BMC Public Health, 15(1): 1-10.

Hidayat S, Yunus F, Susanto AD (2012). Pengaruh polusi udara dalam ruangan terhadap paru. Continuing Medical Education, 39(1): 8-14.

Ibrahim M, Zambruni M, Melby C, Melby P (2017). Impact of childhood malnutrition on host defense and infection. Clinical Microbiology Reviews, 30(4): 919-971.

Jackson S, Mathews KH, Pulanic D,Falconer R, Rudan I, Campbell H, Nair H 
Journal of Epidemiology and Public Health (2018), 3(2): 128-142

https://doi.org/10.26911/jepublichealth.2018.03.02.03

(2013). Risk factors for severe acute lower respiratory infections in children - a systematic review and metaanalysis. Croatian Medical Journal, 54(2): 110-121.

Karsidi R (2008). Sosiologi pendidikan. Surakarta: UNS press.

Kelly MS, Wirth KE, Madrigano J, Feemster KA, Cunningham CK, Arscott T, Finalle R (2016). The effect of exposure to wood smoke on outcomes of childhood pneumonia in Botswana. Int J Tuberc Lung Dis, 19(3): 349355 .

Kementerian Kesehatan RI. (2017). Data dan informasi profil kesehatan Indonesia 2016. Jakarta: Kementerian Kesehatan RI.

Lamberti LM, Zakarija-Grković I, Walker, CLF, Theodoratou E, Nair H, Campbell H, Black RE (2013). Breastfeeding for reducing the risk of pneumonia morbidity and mortality in children under two: a systematic literature review and meta-analysis. BMC Public Health, 13(3), S18. http://doi.org/10.1186/1471-2458-13S3-S18.

Lestari N, Salimo H, Suradi (2017). Role of biopsychosocial factors on the risk of pneumonia in children under-five years old at Dr. Moewardi Hospital Surakarta. Journal of Maternal and Child Health, 2(2): 162-175.

Lu YP, Zeng DY, Chen YP, Liang XJ, Xu JP, Huang SM, Lai ZW, Wen WR, Websky K, Hocher B (2013). Low Birth Weight is Associated with Lower Respiratory Tract Infections in Children with Hand, Foot, and Mouth Disease. Clin. Lab. 59.

Machmud R (2009). Pengaruh kemiskinan keluarga pada kejadian pneumonia balita di Indonesia. Jurnal Kesehatan Masyarakat Nasional, 4(1): 36-41.
Murti B (2016). Prinsip dan metode riset epidemiologi. Surakarta: Yuma Pustaka.

Nguyen TKP, Tran TH, Roberts CL, Graham SM, Marais BJ (2017). Risk factors for child pneumonia - focus on the Western Pacific Region. Paediatric Respiratory Reviews, 21: 102-110.

Nirmolia N, Mahanta TG, Boruah M, Rasaily R, Kotoky RP, Bora R (2017). Prevalence and risk factors of pneumonia in under fi ve children living in slums of Dibrugarh town. Clinical Epidemiology and Global Health, 196: 1- 4.

Oliwa JN, Marais BJ (2017). Vaccines to prevent pneumonia in children - a developing country perspective. Paediatric Respiratory Reviews, 22: 2330.

Padmonobo H, Setiani O, Joko T (2013). Hubungan faktor-faktor lingkungan fisik rumah dengan kejadian pneumonia pada balita di wilayah kerja Puskesmas Jatibarang Kabupaten Brebes. Jurnal Kesehatan Lingkungan I, 11(2): 194-198.

Patel AB, Dhande L A, Pusdekar YV, Borkar JA, Badhoniya NB, Hibberd PL (2013). Childhood illness in households using biomass fuels in India: Secondary data analysis of nationally representative national family health surveys. International Journal of Occupational and Environmental Health, 19(1): 35-42.

Pradhan SM, Rao AP, Pattanshetty SM, Nilima AR (2016). Knowledge and perception regarding childhood pneumonia among mothers of underfive children in rural areas of Udupi Taluk, Karnataka: A cross-sectional study. Indian $\mathrm{J}$ Health Sci Biomed Res. 9:35-9.

Rao S, Kanade AN, Yajnik CS, Fall CHD 
(2009). Seasonality in maternal intake and activity influence offspring's birth size among rural Indian mothers--Pune Maternal Nutrition Study. International Journal of Epidemiology, 38(4): 1094-1103.

Rasyid Z (2013). Faktor-faktor yang berhubungan dengan kejadian pneumonia anak balita di RSUD Bangkinang Kabupaten Kampar. Jurnal Kesehatan Komunitas, 2(3): 136-140.

Sanbata H, Asfaw A, Kumie A (2014). Association of biomass fuel use with acute respiratory infections among under- five children in a slum urban of Addis Ababa, Ethiopia. BMC Public Health, 14(1): 1-8.

Sari EL, Suhartono, Joko T (2014). Hubungan antara kondisi lingkungan fisik rumah dengan kejadian pneumonia pada balita di wilayah kerja Puskesmas Pati I Kabupaten Pati. Jurnal Kesehatan Masyarakat, 2(1): 56-61.

Sigaud CHS, Castanheira ABC, Costa P. Association between secondhand smoking in the home and respiratory morbidity in preschool children. Rev Esc Enferm USP. 206;50(4):562-568. DOI: http://dx.doi.org/10.159o/Soo80-623420160000500004.

Sofia (2017). Environmental risk factors for the incidence of ARI in infants in the working area of the Community Health Center Ingin Jaya District of Aceh Besar. Aceh Nutrition Journal, 2(1): 43-50.

Sood A (2012). Indoor fuel exposure and the lung in both developing and developed countries: An update. Clin Chest Med. 33(4): 649-665.

Stekelenburg J, Kashumba E, Wolffers I (2002). Factors contributing to high mortality due to pneumonia among under-fives in Kalabo District, Zam- bia. Tropical Medicine and International Health, 7(10): 886-893.

Suzuki M, Thiem VD, Yanai H, Matsubayashi T, Yoshida LM, Tho LH, Ariyoshi K (2009). Association of environmental tobacco smoking exposure with an increased risk of hospital admissions for pneumonia in children under 5 years of age in Vietnam. Thorax, 64(6): 484-489.

Wang MC, Kim S, Gonzalez AA, MacLeod KE, Winkleby MA (2007). Socioeconomic and food-related physical characteristics of the neighbourhood environment are associated with body mass index. Journal of Epidemiology and Community Health, 61(6): 491498.

WHO \& UNICEF (2013). Ending preventable child deaths from pneumonia and diarrhoea by 2025: The integrated Global Action Plan for Pneumonia and Diarrhoea (GAPPD). Geneva.

WHO \& UNICEF (2015). Pneumonia The Deadliest Childhood Disease. https://data.unicef.org/topic/child-health/pneumonia/. Diakses April 2017.

Wichmann J, Voyi KVV (2006). Impact of cooking and heating fuel use on acute respiratory health of preschool children in South Africa. The Southern African Journal of Epidemiology and Infection, 21(2): 48-54.

World Bank (2012). Indonesia: Health Impacts of Indoor Air Pollution. Australia.www.who.int/indoorair/hea lth_impacts/en/. Diakses April 2017.

Wulandari E (2014). Faktor yang berhubungan dengan keberadaan Streptococcus di udara pada rumah susun Kelurahan Bandarharjo Kota Semarang Tahun 2013. Unnes Journal of Public Health, 3(4): 1-10.

Yunita A, Murti B, Dewi YLR (2016). Multilevel Analysis on the Bio- 
Journal of Epidemiology and Public Health (2018), 3(2): 128-142

https://doi.org/10.26911/jepublichealth.2018.03.02.03

psychosocial and Environment Factors Affecting the Risk of Pneumonia in Infants. Journal of Epidemiology and Public Health (2016), 1(1): 1-10.

Zairinayati, Udiyono A, Hanani Y (2013). Analisis faktor lingkungan fisik rumah yang berhubungan dengan kejadian pneumonia pada balita di wilayah kerja Puskesmas Sosial Kecamatan Sukarame Palembang. Jurnal Kesehatan Lingkungan, 1(2): 1-10.

Zar HJ, Madhi SA, Aston SJ, Gordon SB (2013). Pneumonia in low and middle income countries: Progress and challenges. Thorax, 68(11): 10521056. 